Article

\title{
Spectroscopic Determination of Water Salinity in Brackish Surface Water in Nandoni Dam, at Vhembe District, Limpopo Province, South Africa
}

\author{
Lebea N. Nthunya ${ }^{1,2, *(\mathbb{D})}$, Sebabatso Maifadi ${ }^{1}$, Bhekie B. Mamba ${ }^{1}$, Arne R. Verliefde ${ }^{2}$ and \\ Sabelo D. Mhlanga ${ }^{1}$ \\ 1 Nanotechnology and Water Sustainability Research Unit, College of Science, Engineering and Technology, \\ University of South Africa, Florida, Johannesburg 1709, South Africa; s.tsieane@gmail.com (S.M.); \\ mambabb@unisa.ac.za (B.B.M.); sdmhlanga1@gmail.com (S.D.M.) \\ 2 Particle and Interfacial Technology Group, Department of Green Chemistry and Technology, \\ Ghent University, Coupure Links 653, 9000 Ghent, Belgium; arne.verliefde@ugent.be \\ * Correspondence: lebea.nthunya@ugent.be; Tel.: +32-496-03-56-05
}

Received: 22 June 2018; Accepted: 21 July 2018; Published: 27 July 2018

\begin{abstract}
The problem of limited water supply in the Vhembe District (Limpopo Province, South Africa) is exacerbated by a preponderance of dissolved salts, which cause disagreeable taste and odour in the water as reported by the communities using this water for drinking. The water treatment plant that supplies the treated water to the communities in the District sources this raw water from the Nandoni Dam at the Luvuvhu river catchment. There are no scientific studies that have been reported in the literature that focused on determining the levels of water salinity from various water sources in the municipalities of the District. Water samples from various sites across the Nandoni Dam, a primary source of domestic water supply in the region, were collected through each season over a period of twelve months in order to ascertain the concentrations of dissolved salts in the dam. Onsite analyses of the water samples were conducted using the YSI ProDSS multimeter, while the laboratory water analyses were conducted using the spectroquant and atomic absorption spectrometers. Although salinity tests seem to indicate that the water sampled across most of the Nandoni Dam is brackish during all seasons of the year with the highest being $750 \mathrm{mg} / \mathrm{L}$, water samples from the dam mid-outlet and the treatment plant are slightly below the World Health Organization (WHO) brackish water bracket of $500 \mathrm{mg} / \mathrm{L}$ with unfavourable taste for drinking. Results from this study indicate that the water sourced from the Nandoni Dam is not suitable for human consumption and therefore requires integrated water resource management, as well as robust and cost-effective water desalination treatment.
\end{abstract}

Keywords: contamination; domestic use; Nandoni Dam; salinity; water analysis

\section{Introduction}

The quality of available water resources in rural settlements in most provinces of South Africa is poor $[1,2]$. For example, water supplied by a local water treatment plant to about fifty-five villages in the Thulamela Local Municipality of the Vhembe District Municipality, Limpopo Province is reported to be salty although there is no scientific information provided [3]. Fouche et al. have reportedly demonstrated that the phosphates, nitrates and ammonium levels in Nandoni Dam are not suitable for fisheries [4]. For some years, the residents of this municipality have been complaining about the quality of the water, which they use for irrigation and domestic purposes. Besides the poor water quality, the salts found in the water accumulate in the distribution network resulting in blockages of the 
pipelines. High concentrations of salts, metals, and possibly other contaminants (i.e., total dissolved solids) cause scale build-up on the surface of plumbing fixtures and appliances such as taps, which are used for the conveyance of water to the end-user. Figure 1 shows salt deposits that have accumulated over a period of time on the surface of a water tap in Limpopo Province, South Africa.

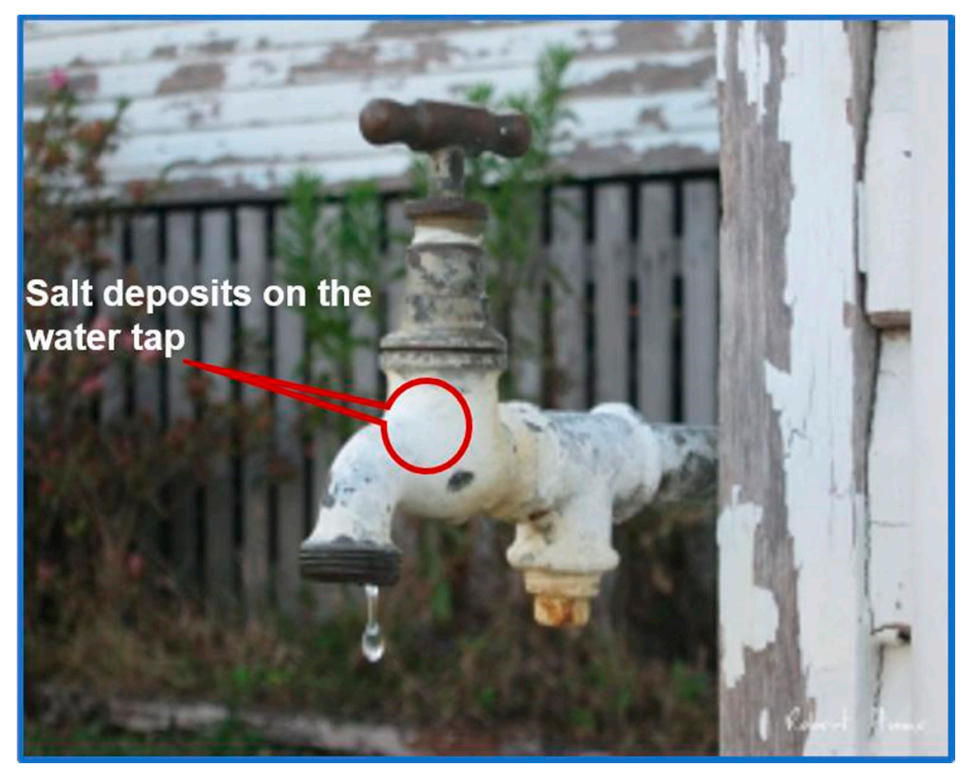

Figure 1. A picture showing public water tap with a salt deposit in Limpopo Province, South Africa [5].

Although the residents could not determine the extent of the salinity of the water, it is thought to be brackish water since the salty taste of the water was to some extent tolerable. The water salinity is the amount of the dissolved salts in the body of water. These dissolved salts include sodium chloride, magnesium sulphates, potassium nitrates, and sodium bicarbonate. Brackish water by definition has a salty, disagreeable taste and a higher salinity when compared with fresh water, but not as saline as sea water [6]. Brackish water refers to water with salinity of 500-17,000 mg/L [7]. To put this technical definition into perspective, seawater and salt lakes have a salt concentration of about 30,000-40,000 mg/L.

Brackish water is mostly found in estuarine areas where seawater mixes with freshwater [8]. Other than estuaries, the elevated groundwater salinity can be observed in the regions where groundwater is in contact with evaporates formations, or mixed with high mineralized and deeper aquifers [9,10]. The discharges from industrial effluents containing dissolved salts, leachates of saline soils and the runoff of salt deposits such as halite or gypsum that is present in the sedimentary rocks also increase the amounts of total dissolved salts and thus lead to the formation of brackish water [11-13]. However, the primary contributing source of brackish surface water (e.g., brackish dam water) is the mixing of the saline water from the open wells and the fresh water as well as the flow from the saline aquifer sourced from pumping wells to the surface water [14]. These mentioned sources are the main practices in Vhembe district and they are therefore the main likely sources of saline water in Nandoni Dam.

The salinity in the water affects the quality of water that is used for drinking, irrigation, and industrial applications. It also impacts on various social, economic and environmental related uses by both rural and urban communities [15-19]. The high levels of salt deposits cause an unfavourable hydrological environment in water that restricts its domestic use such as for drinking and normal production of crops $[17,20]$. Scale build-up due to water salinity also necessitates increased frequency and cost of repair and maintenance of the public infrastructure [21]. In addition, the salt deposits corrode bricks, pavements, concrete and destroy the bitumen properties thus leading to erosion of roads [22,23]. 
Although the brackish water is an unfavourable resource, it still provides a secondary or alternative source of water that is less costly for purification compared to seawater [24]. However, good estimates of the salinity of the water to be purified should be established in order to define the possibility of assigning that particular water resource as a potential and alternative water resource [25]. It should however also be borne in mind that certain ions such as fluorides and nitrates would also require specialized treatment [25]. Therefore, this study seeks to determine levels of water salinity as well as ions that contribute to water salinity in the Nandoni Dam. The water salinity was monitored for a period of twelve months to ascertain the variability induced by different factors such as rainfalls between the four seasons of the year (spring, summer, autumn and winter). This dam is a source of water that is treated by the municipal treatment plant which is then distributed to Thulamela Local Municipality and other nearby municipalities in Vhembe District for domestic purposes.

\section{Experimental Design}

\subsection{Materials}

Calcium carbonate $\left(\mathrm{CaCO}_{3}, 99.95 \%\right.$, analytical reagent), magnesium $(\mathrm{Mg}, 99.99 \%$ trace metals basis), sodium chloride ( $\mathrm{NaCl}, 99.5 \%$ volumetric standard), lanthanum oxide $\left(\mathrm{La}_{2} \mathrm{O}_{3}\right.$ 99.9\% AAS grade), hydrochloric acid ( $\mathrm{HCl}, 37 \%$, reagent grade) were purchased from Sigma Aldrich (Germany). Polyvinylidene fluoride (PVDF) durapore filter membranes with pore size of $0.45 \mu \mathrm{m}$, the chloride $\left(\mathrm{Cl}^{-}\right)$, nitrate $\left(\mathrm{NO}_{3}{ }^{-}\right)$, sulphate $\left(\mathrm{SO}_{4}{ }^{2-}\right)$, phosphate $\left(\mathrm{PO}_{4}{ }^{3-}\right)$, fluoride $\left(\mathrm{F}^{-}\right)$, iodide $\left(\mathrm{I}^{-}\right)$, ammonium $\left(\mathrm{NH}_{4}{ }^{+}\right)$spectroquant cell and reagent test kits were purchased from Merck (South Africa). De-ionized water was prepared from our lab using Direct-Q® (Millipore) system supplied by Merck Millipore (South Africa). All reagents were used as received.

\subsection{Sampling Location}

The study area was water bodies in and around Nandoni Dam, at Vhembe District, Limpopo Province, South Africa. The geographic coordinates of the sampling points were identified using civilian global positioning system (GPS) with a $5 \mathrm{~m}$ horizontal accuracy. The coordinates for each sampling point are summarized in Table 1. The geographical view of the sampling points is shown in Figure 2.

Table 1. The geographical location of the sampling points (the dam and treatment plant water sources used in this study), Nandoni Dam, Vhembe District, Limpopo Province, South Africa.

\begin{tabular}{clll}
\hline Sampling Point & \multicolumn{2}{c}{ GPS Coordinates } & \multicolumn{1}{c}{ Description } \\
\hline Dam Inlet & $-22.99835^{\circ}$ South & $30.51354^{\circ}$ East & $\begin{array}{l}\text { The dam entrance located nearby the } \\
\text { bridge between the dam and Luvuvhu } \\
\text { River in Muledane village. }\end{array}$ \\
\hline Dam Near-Inlet & $-22.99687^{\circ}$ South & $30.54071^{\circ}$ East & $\begin{array}{l}\text { The middle entrance was located } 4.6 \mathrm{~km} \\
\text { away from the dam exit. }\end{array}$ \\
\hline Dam Near-Outlet & $-22.98237^{\circ}$ South & $30.57476^{\circ}$ East & $\begin{array}{l}\text { The middle exit point was located at } 2.7 \mathrm{~km} \\
\text { away from the dam exit. }\end{array}$ \\
\hline Dam Outlet & $-22.97901^{\circ}$ South & $30.59336^{\circ}$ East & $\begin{array}{l}\text { The dam exit is } 100 \mathrm{~m} \text { away from the } \\
\text { Thohoyandou bridge. }\end{array}$ \\
\hline Municipal WTP & $-23.255636^{\circ}$ South & $30.77175^{\circ}$ East & $\begin{array}{l}\text { This treatment plant sources the water from } \\
\text { Nandoni Dam for purification and } \\
\text { distribution. The water is collected at the } \\
\text { rate of } 60 \times 10^{6} \text { L /day within the distance } \\
\text { of } 30.7 \mathrm{~km} \text { from the dam closer to the outlet }\end{array}$ \\
\hline
\end{tabular}

Note: The raw and treated water were collected at the treatment plant. 


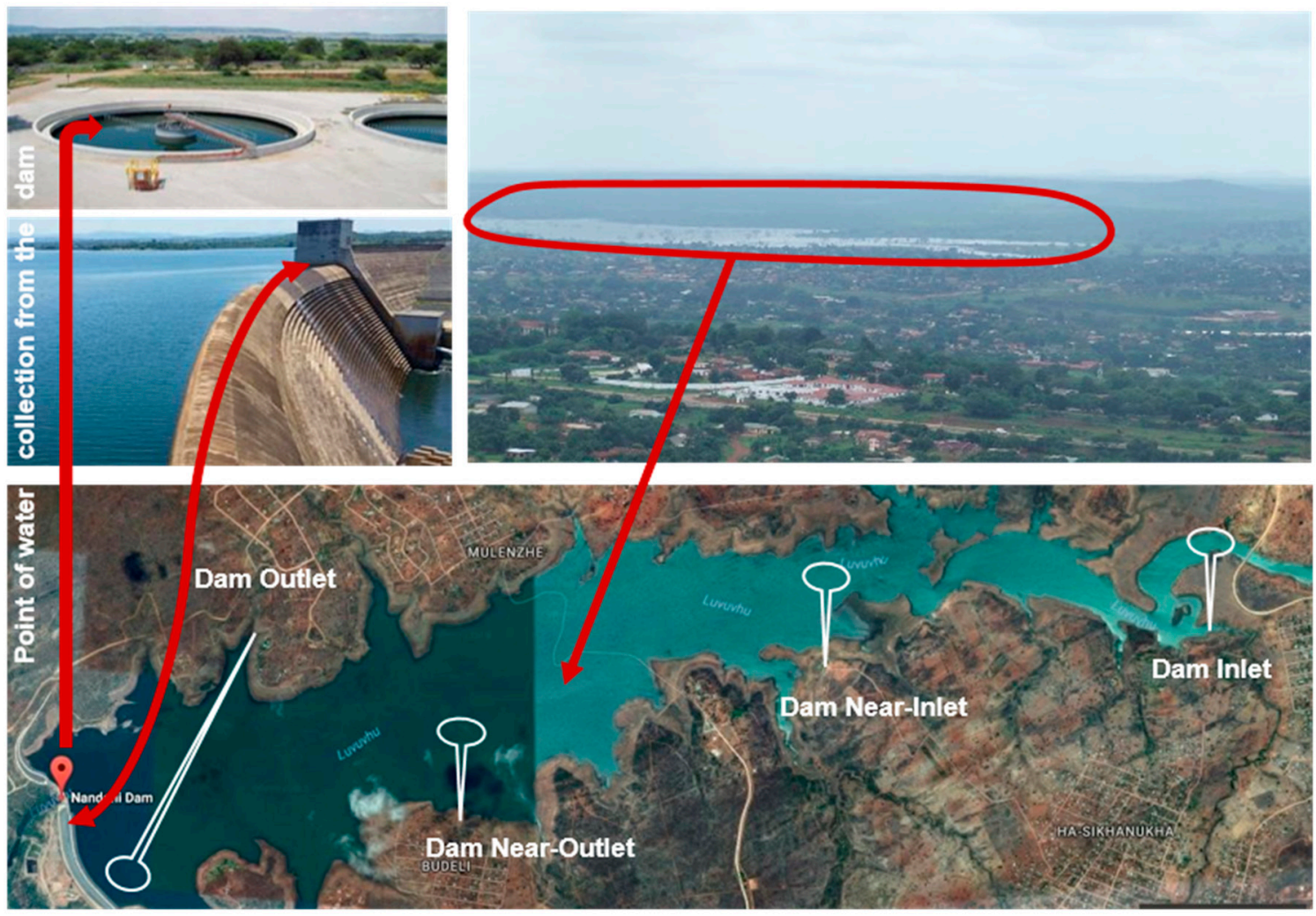

Figure 2. An overview of the sampling points located using Google Maps.

\subsection{On-Site Analysis}

The physical-chemical parameters of water, including conductivity, total dissolved solids (TDS), salinity, temperature and $\mathrm{pH}$ of the collected water samples were measured in situ using a YSI ProDSS Multi-Parameter Water Quality Meter (YSI Incorporated, Yellow Springs, OH, USA) with the sampling probe installed to the dam. The water samples collected for laboratory analysis were taken at 1-m depth from the surface of the water and kept in the cooler box during transportation to the laboratories.

\subsection{Preparation of Standard Aqueous Solutions}

The $50 \mathrm{mg} / \mathrm{L}$ stock solutions of $\mathrm{CaCl}$ and $\mathrm{MgCl}$ were prepared by separately dissolving each of $\mathrm{CaCO}_{3}$ and $\mathrm{Mg}$ in $0.1 \mathrm{M} \mathrm{HCl}$. The $50 \mathrm{mg} / \mathrm{L} \mathrm{NaCl}$ stock solution was on the other hand prepared by dissolving $\mathrm{NaCl}$ in de-ionized water. The working standards were prepared by the serial volume/volume dilutions of the stock solutions. Seven working standards $(0.5 \mathrm{mg} / \mathrm{L}, 1 \mathrm{mg} / \mathrm{L}$, $2 \mathrm{mg} / \mathrm{L}, 4 \mathrm{mg} / \mathrm{L}, 8 \mathrm{mg} / \mathrm{L}, 16 \mathrm{mg} / \mathrm{L}, 32 \mathrm{mg} / \mathrm{L}$ for all metal ions) were used to prepare calibration graphs. The stock solution of $\mathrm{LaCl}_{3}-\mathrm{HCl}$ that was used to mask the AAS interferences was prepared by dissolving $58 \mathrm{~g}$ of lanthanum oxide $\left(\mathrm{La}_{2} \mathrm{O}_{3}\right)$ in $250 \mathrm{~mL}$ of $12 \mathrm{M} \mathrm{HCl}$ and diluted to a total volume of $500 \mathrm{~mL}$ using de-ionized water.

\subsection{Atomic Absorption Spectroscopy (AAS) Analysis of Metal Ions}

The analysis of metal ions was performed using the atomic absorption spectrometer under the following conditions: gratings-visible for calcium and sodium, and ultraviolet for magnesium; wavelength counters-211.4 (4227 A), 285.2 (2852 A) and 294.4 (5888 A); sources—calcium hollow cathode lamp, magnesium hollow cathode lamp and sodium vapour discharge lamp; lamp current-10 mA, $20 \mathrm{~mA}$ and $900 \mathrm{~mA}$ were used for calcium, sodium and magnesium, respectively. The analysis was undertaken under an air pressure of $28 \mathrm{psi}$, the fuel (acetylene) pressure of 8 psi and the sample uptake of $4 \mathrm{~mL}$. The samples were filtered using $0.45 \mu \mathrm{m}$ filters and $0.4 \mathrm{~mL}$ of $\mathrm{LaCl}-\mathrm{HCl}$ was added 
to each sample prior to analysis. The percentage absorption was recorded for each atomized sample. The percentage absorption was converted to absorbance, which was subsequently used to calculate the concentration of each analyte.

\subsection{The Spectroquant Analysis of Anions}

The concentrations of all anions $\left(\mathrm{Cl}^{-}, \mathrm{NO}_{3}{ }^{-}, \mathrm{SO}_{4}{ }^{2-}, \mathrm{PO}_{4}{ }^{3-}, \mathrm{F}^{-}, \mathrm{I}^{-}\right)$under investigation as well as $\mathrm{NH}_{4}{ }^{+}$were determined using spectroquant photometry which is USEPA approved. The advantages of the technique lie in its simplicity to operate, cost-effectiveness and the ability to analyze a variety of analytes. Spectroquant is a pre-programmed method that is inclusive of the latest micro-process technology with high quality optical and electronic components. The reagents that are specific to individual analytes are provided as both liquids and powders and possess buffering capacity to prevent the $\mathrm{pH}$ variations. The spectrometer was optimized to correlate the absorbance of the analyte of interest using the barcode of the test cell of each analyte. To determine the concentration of each analyte, the provided kit reagents were added into the sample of the analyte to produce the characteristic colour that will absorb the UV-Vis light, hence measuring the concentrations of each anion [26,27]. During the analyte measurements, the spectroquant photometer indicated if the limit of detection and quantification had been exceeded. The analyte with the concentration that falls within the measuring range was detected. Therefore, the analytes with concentrations higher than the detectable limits were diluted and the dilution factors were used to calculate the concentration of such analyte in the water collected from Nandoni Dam. The calibration graphs were prepared using different concentration ranges of different analytes. For instance, the calibration graph for chlorides analysis, was prepared from a total of seven working standards $(0.25 \mathrm{mg} / \mathrm{L}, 5 \mathrm{mg} / \mathrm{L}, 25 \mathrm{mg} / \mathrm{L}$, $50 \mathrm{mg} / \mathrm{L}, 100 \mathrm{mg} / \mathrm{L}, 200 \mathrm{mg} / \mathrm{L}, 250 \mathrm{mg} / \mathrm{L}$ ). The instrument was switched to the absorbance mode where the absorbance of the deionized water and the chlorides at these concentrations were measured. The coefficients of determination which were greater than 0.99 were observed for all analytes. The limit of the detection, and the limit of quantification were calculated and were found to correspond to the ones provided in the test kits.

\subsection{Statistical Analysis}

Two statistical analyses were used to determine the variance of the water salinity. One-way analysis of variance (ANOVA) was carried out to evaluate the variation of water quality parameters. The physicochemical variables in this analysis are: electrical conductivity (EC), total dissolved solids (TDS), salinity, chlorides $\left(\mathrm{Cl}^{-}\right)$, nitrate $\left(\mathrm{NO}_{3}{ }^{-}\right)$, phosphates $\left(\mathrm{PO}_{4}{ }^{3-}\right)$, sulphates $\left(\mathrm{SO}_{4}{ }^{2-}\right)$, fluoride $\left(\mathrm{F}^{-}\right)$, iodide $(\mathrm{I})$, ammonium $\left(\mathrm{NH}_{4}{ }^{-}\right)$, sodium $\left(\mathrm{Na}^{+}\right)$, magnesium $\left(\mathrm{Mg}^{2+}\right)$, calcium $\left(\mathrm{Ca}^{2+}\right)$, hydrogen carbonate $\left(\mathrm{HCO}_{3}{ }^{-}\right)$.

Student's $t$-test was used to determine whether water quality parameters of the particular site demonstrated that the water was brackish or not. The null hypothesis was that the water in Nandoni Dam was brackish. The statistical test for student's $(t)$ is given by the Equation (1) to compare each parameter of a particular site with a defined standard:

$$
t=\frac{\bar{x}-\mu}{s / \sqrt{ } n}
$$

where $\bar{x}$ is the mean value of the examined parameter, $s$ is the standard deviation and $n$ is the sample size.

\section{Results and Discussion}

\subsection{Physico-Chemical Analysis}

The physicochemical properties of the water samples such as conductivity, total dissolved solids (TDS), salinity, temperature, and $\mathrm{pH}$ were measured at the field where the samples were 
collected. The water samples were collected between the period of twelve months and the results of the physicochemical parameters that were measured are presented in Table 2. Three representative samples per sampling were collected in each identified sampling point within the dam and municipal treatment plant that sourced the water from the dam for purification.

Table 2. The physicochemical indicators of the water quality in the Nandoni Dam (conductivity, TDS, salinity, temperature, and $\mathrm{pH}$ ) for the water samples collected in spring and summer 2016, autumn and winter 2017.

\begin{tabular}{|c|c|c|c|c|c|c|}
\hline $\begin{array}{c}\text { Sampling } \\
\text { Point }\end{array}$ & $\begin{array}{c}\text { Sampling } \\
\text { Season }\end{array}$ & $\begin{array}{c}\text { Conductivity } \\
\mu S / \mathrm{cm}\end{array}$ & TDS mg/L & $\begin{array}{l}\text { Salinity } \\
\mathrm{mg} / \mathrm{L}\end{array}$ & $\begin{array}{c}\text { Temperature } \\
\text { K }\end{array}$ & $\mathrm{pH}$ \\
\hline \multirow{4}{*}{ Dam inlet } & Spring & $1468 \pm 68$ & $954 \pm 42$ & $712 \pm 33$ & $292 \pm 6$ & $7.95 \pm 0.34$ \\
\hline & Summer & $1395 \pm 45$ & $903 \pm 45$ & $633 \pm 12$ & $298 \pm 9$ & $8.23 \pm 0.45$ \\
\hline & Autumn & $1321 \pm 52$ & $833 \pm 33$ & $541 \pm 36$ & $299 \pm 8$ & $7.65 \pm 0.21$ \\
\hline & Winter & $1352 \pm 23$ & $912 \pm 42$ & $625 \pm 25$ & $294 \pm 5$ & $8.02 \pm 0.35$ \\
\hline \multirow{4}{*}{$\begin{array}{c}\text { Dam } \\
\text { Mid-Inlet }\end{array}$} & Spring & $1835 \pm 65$ & $910 \pm 21$ & $751 \pm 10$ & $293 \pm 5$ & $7.61 \pm 0.22$ \\
\hline & Summer & $1820 \pm 12$ & $958 \pm 33$ & $610 \pm 18$ & $298 \pm 10$ & $7.83 \pm 0.32$ \\
\hline & Autumn & $1785 \pm 44$ & $821 \pm 49$ & $532 \pm 34$ & $297 \pm 4$ & $7.78 \pm 0.11$ \\
\hline & Winter & $1798 \pm 35$ & $897 \pm 22$ & $586 \pm 35$ & $292 \pm 12$ & $7.36 \pm 0.24$ \\
\hline \multirow{4}{*}{$\begin{array}{c}\text { Dam } \\
\text { Mid-outlet }\end{array}$} & Spring & $1358 \pm 54$ & $864 \pm 12$ & $469 \pm 17$ & $294 \pm 3$ & $7.15 \pm 0.09$ \\
\hline & Summer & $1318 \pm 25$ & $852 \pm 33$ & $417 \pm 9$ & $298 \pm 10$ & $7.90 \pm 0.42$ \\
\hline & Autumn & $1301 \pm 56$ & $812 \pm 44$ & $364 \pm 18$ & $299 \pm 18$ & $8.11 \pm 0.23$ \\
\hline & Winter & $1311 \pm 43$ & $798 \pm 43$ & $523 \pm 38$ & $293 \pm 7$ & $7.35 \pm 0.35$ \\
\hline \multirow{4}{*}{ Dam Outlet } & Spring & $1685 \pm 63$ & $985 \pm 13$ & $716 \pm 14$ & $292 \pm 4$ & $7.73 \pm 0.34$ \\
\hline & Summer & $1717 \pm 32$ & $1194 \pm 32$ & $634 \pm 23$ & $298 \pm 14$ & $7.82 \pm 0.14$ \\
\hline & Autumn & $1699 \pm 23$ & $1154 \pm 41$ & $445 \pm 32$ & $298 \pm 3$ & $7.25 \pm 0.41$ \\
\hline & Winter & $1765 \pm 55$ & $1245 \pm 34$ & $526 \pm 22$ & $292 \pm 5$ & $7.35 \pm 0.32$ \\
\hline \multirow{4}{*}{ WTP TW } & Spring & $772 \pm 32$ & $646 \pm 29$ & $309 \pm 33$ & $291 \pm 11$ & $7.35 \pm 0.13$ \\
\hline & Summer & $565 \pm 66$ & $705 \pm 36$ & $258 \pm 8$ & $297 \pm 8$ & $7.84 \pm 0.35$ \\
\hline & Autumn & $721 \pm 41$ & $882 \pm 18$ & $221 \pm 42$ & $298 \pm 4$ & $8.13 \pm 0.28$ \\
\hline & Winter & $685 \pm 65$ & $695 \pm 10$ & $336 \pm 35$ & $291 \pm 5$ & $7.68 \pm 0.35$ \\
\hline \multirow{4}{*}{ WTP RW } & Spring & $985 \pm 33$ & $715 \pm 34$ & $408 \pm 31$ & $292 \pm 10$ & $7.89 \pm 0.21$ \\
\hline & Summer & $912 \pm 47$ & $722 \pm 35$ & $361 \pm 12$ & $297 \pm 8$ & $8.19 \pm 0.17$ \\
\hline & Autumn & $854 \pm 69$ & $717 \pm 14$ & $325 \pm 27$ & $296 \pm 4$ & $8.21 \pm 0.31$ \\
\hline & Winter & $978 \pm 45$ & $698 \pm 36$ & $464 \pm 21$ & $291 \pm 11$ & $7.77 \pm 0.10$ \\
\hline
\end{tabular}

Notes: WTP is the treatment plant, TW is the treated water, RW is the raw water.

The water samples in the Nandoni Dam were found to be slightly alkaline with a $\mathrm{pH}$ ranging from 7.19 to 8.23 (Table 2). This was expected since the water passes through various limestone rocks prior to collection into the Nandoni Dam. This meant the water contains the carbonates at concentrations that have neutralization effect to result in the formation of slightly alkaline $\mathrm{pH}$. The Nandoni Dam is also surrounded by activities that involve discharges from a sewer network, irrigation canals, drainage network and pumped groundwater which find their way to the lake via several tributaries. These activities result to the $\mathrm{pH}$ fluctuations depending on their hydronium and hydroxide ion dissociation potentials in water [28,29].

The temperature of the water samples was found to significantly vary with seasonal changes. In this regard, lower temperatures $(291 \mathrm{~K})$ were recorded during winter and the highest temperature ( $298 \mathrm{~K})$ was recorded during summer. A significant variation in the seasonal water temperature (spring $292 \mathrm{~K}$; summer $298 \mathrm{~K}$ in 2016; autumn $295 \mathrm{~K}$; and winter $291 \mathrm{~K}$ in 2017) was caused by an increased cooling rate of the water bodies due to the exposure of the dam to the wind. Large open water bodies have a fast cooling rate with respect to wind direction and this results in colder water during winter and spring, and warmer water during summer and autumn [30].

The conductivity of the water is a measure of the concentration of ions that are capable of carrying electrical current [7]. Water conductivity is used to estimate the TDS and salinity of the water. The conductivity, TDS and salinity classification of fresh, brackish and sea water is presented in Table $3[6,31]$. The conductivity of the water sampled from the dam was found to be higher at the 
middle inlet and outlet of the dam. Apart from the Luvuvhu River, the Nandoni Dam has other small streams that enter the dam. These streams are most likely to deposit high amounts of total dissolved solids, which lead to an increase in the water conductivity. By all accounts, the conductivity values obtained for the water samples of the Nandoni Dam and the municipality treatment plant indicate brackish water.

Table 3. The conductivity, TDS, and salinity of fresh, brackish and seawater [6,31-33].

\begin{tabular}{cccc}
\hline \multirow{2}{*}{ Water Salinity } & \multicolumn{3}{c}{ Physico-Chemical Properties } \\
\cline { 2 - 4 } & Conductivity $(\mu \mathrm{S} / \mathrm{cm})$ & TDS $(\mathbf{m g} / \mathrm{L})$ & Salinity $(\mathbf{m g} / \mathrm{L})$ \\
\hline Fresh water & $150-500$ & $<1000$ & $<500$ \\
Brackish water & $1000-80,000$ & $1000-5000$ & $500-17,000$ \\
Sea water & 55,000 & $30,000-40,000$ & $35,000-40,000$ \\
Brine & $\geq 55,000$ & $\geq 100,000$ & $\geq 50,000$ \\
\hline
\end{tabular}

The total dissolved solids (TDS) are comprised of inorganic matter such as mineral, salts, metals as well as dissolved organic compounds present in the water [34]. In general, the high concentrations of TDS (1194 and $1154 \mathrm{mg} / \mathrm{L}$ ) were observed during the rainy seasons (i.e., summer and autumn respectively). Such levels are associated with the run-off that carries high deposits of the dissolved compounds into the Nandoni Dam. The total dissolved solids were concentrated at the dam outlet with the highest concentration of $1245 \mathrm{mg} / \mathrm{L}$ being recorded in winter.

Salinity is a measure of the total concentration of all dissolved salts in water [35]. The salinity of the water in the Nandoni Dam was found to be higher during the dry seasons (i.e., winter and spring) with the highest amount $(750 \mathrm{mg} / \mathrm{L})$ being recorded for the water sampled at the middle of the dam near inlet. This is attributable to the low dilution effect of the total dissolved salts, which are presently deposited into the dam during the dry seasons. The salinity values seem to suggest that the water in the bulk of the Nandoni Dam was brackish [32,33]. A few exceptions were however noted; the water at the dam outlet and the treatment plant (the plant that sources the water from Nandoni Dam for treatment prior to distribution) indicate that this water falls within the freshwater category (i.e., salinity <500 mg/L), although the water taste is unsatisfactory when drinking.

Fresh, brackish and seawater possess viable minerals that differ in availability and concentration. The concentrations of the common ions present in fresh, brackish and sea water are shown in Table 4 . The concentration ranges of these ions serve as a guide to water management authorities for monitoring of the presence of dissolved salts in surface water. In the Vhembe District, communities rely on both ground and dam waters for domestic use.

Table 4. A comparison of the concentration ranges of mineral ions present in fresh and saline water [6,36-39].

\begin{tabular}{cccc}
\hline \multirow{2}{*}{ Ions } & \multicolumn{3}{c}{ Concentration $(\mathrm{mg} / \mathrm{L})$} \\
\cline { 2 - 4 } & Fresh Water & Brackish Water & Sea Water \\
\hline Chloride & $1-250$ & $500-5000$ & 19,000 \\
Nitrate & $0-18$ & - & 0.7 \\
Phosphate & - & - & 0.1 \\
Sulphate & - & $10-800$ & - \\
Fluoride & - & - & 1.4 \\
Iodide & - & - & 0.05 \\
Ammonium & - & - & 0.05 \\
Hydrogen carbonate & - & $100-360$ & 145 \\
Sodium & $\geq 200$ & $5-800$ & 10,000 \\
Magnesium & - & $5-80$ & 1290 \\
Calcium & - & $30-350$ & 400 \\
\hline
\end{tabular}


However, the presence of the dissolved salts from the water sourced from Nandoni Dam may pose a health danger to the people using this water for drinking, as there are no physical indicators on the quality of water being consumed.

The concentrations of all mineral ions that constitute water salinity were determined and the results are presented in Table 5 . The amounts of all ions studied were found to be significantly different throughout the seasons, with higher concentrations being observed during dry seasons (i.e., winter and spring). However, the detection of individual ions such as chloride and sodium ions demonstrated that the water in the Nandoni Dam was moderately saline, with chloride and sodium ion concentrations being below those of brackish water.

Although the ion concentrations of the Nandoni Dam are lower than those of brackish water, their total chemical interactions may lead to compromised water quality with unfavourable taste (too salty for drinking) and odour. For instance, sodium is available in water bodies in several chemical compositions that include sodium chloride, sodium carbonate, sodium sulphate, sodium phosphate, sodium bicarbonate and others.

Table 5. The concentration of the mineral ions that contribute towards water salinity in the Nandoni Dam for the water samples collected in spring and summer 2016, and autumn and winter 2017.

\begin{tabular}{|c|c|c|c|c|c|c|c|c|c|c|c|c|}
\hline $\begin{array}{l}\text { Sampling } \\
\text { Point }\end{array}$ & $\begin{array}{c}\text { Sampling } \\
\text { Season }\end{array}$ & $\begin{array}{c}\mathrm{Cl}^{-} \\
\mathrm{mg} / \mathrm{L}\end{array}$ & $\begin{array}{c}\mathrm{NO}_{3}^{-} \\
\mathrm{mg} / \mathrm{L}\end{array}$ & $\begin{array}{c}\mathrm{PO}_{4}{ }^{3-} \\
\mathrm{mg} / \mathrm{L}\end{array}$ & $\begin{array}{c}\mathrm{SO}_{4}^{2-} \\
\mathrm{mg} / \mathrm{L}\end{array}$ & $\begin{array}{c}\mathrm{F}^{-} \\
\mathrm{mg} / \mathrm{L}\end{array}$ & $\begin{array}{c}\mathrm{I}^{-} \\
\mathrm{mg} / \mathrm{L}\end{array}$ & $\begin{array}{l}\mathrm{NH}_{4}{ }^{+} \\
\mathrm{mg} / \mathrm{L}\end{array}$ & $\begin{array}{c}\mathrm{Na}^{+} \\
\mathrm{mg} / \mathrm{L}\end{array}$ & $\begin{array}{l}\mathrm{Mg}^{2+} \\
\mathrm{mg} / \mathrm{L}\end{array}$ & $\begin{array}{c}\mathrm{Ca}^{2+} \\
\mathrm{mg} / \mathrm{L}\end{array}$ & $\begin{array}{c}\mathrm{HCO}^{3-} \\
\mathrm{mg} / \mathrm{L}\end{array}$ \\
\hline \multirow{4}{*}{ Dam Inlet } & Spring & 59.5 & 8.06 & 1.25 & 0.3 & 0.08 & 1.32 & 0.32 & 34.86 & 6.76 & 25.21 & 44.35 \\
\hline & Summer & 64.6 & 16.12 & 1.01 & 0.6 & 0.06 & 1.04 & 1.32 & 38.63 & 6.68 & 22.25 & 33.25 \\
\hline & Autumn & 25.5 & 7.02 & 1.48 & 0.9 & 0.06 & 1.56 & 2.21 & 16.08 & 4.51 & 19.09 & 41.32 \\
\hline & Winter & 35.7 & 5.98 & 1.25 & 0.6 & 0.05 & 1.29 & 2.28 & 15.86 & 4.42 & 29.79 & 45.65 \\
\hline \multirow{4}{*}{$\begin{array}{c}\text { Dam } \\
\text { Mid-Inlet }\end{array}$} & Spring & 110.7 & 19.5 & 1.73 & 0.3 & 0.09 & 1.82 & 3.45 & 55.33 & 4.50 & 19.36 & 38.25 \\
\hline & Summer & 76.5 & 20.54 & 1.12 & 0.6 & 0.04 & 1.04 & 2.45 & 45.86 & 6.47 & 16.85 & 22.65 \\
\hline & Autumn & 30.6 & 7.54 & 1.51 & 0.3 & 0.09 & 1.56 & 5.25 & 17.65 & 9.54 & 17.66 & 24.85 \\
\hline & Winter & 37.4 & 5.72 & 1.69 & 0.9 & 0.08 & 1.82 & 4.26 & 17.27 & 17.99 & 20.54 & 35.45 \\
\hline \multirow{4}{*}{$\begin{array}{c}\text { Dam } \\
\text { Mid-Outlet }\end{array}$} & Spring & 114.1 & 20.28 & 1.250 & 0.6 & 0.07 & 1.35 & 4.24 & 34.75 & 7.57 & 15.49 & 19.52 \\
\hline & Summer & 76.5 & 31.46 & 1.75 & 0.3 & 0.06 & 1.82 & 5.12 & 44.89 & 7.65 & 13.59 & 22.58 \\
\hline & Autumn & 69.7 & 5.21 & 1.54 & 0.9 & 0.05 & 1.56 & 4.69 & 18.86 & 5.11 & 12.66 & 17.96 \\
\hline & Winter & 37.4 & 5.98 & 1.42 & 0.6 & 0.05 & 1.56 & 4.19 & 18.90 & 5.41 & 14.35 & 24.85 \\
\hline \multirow{4}{*}{$\begin{array}{l}\text { Dam } \\
\text { Outlet }\end{array}$} & Spring & 54.4 & 3.64 & 1.54 & 0.6 & 0.06 & 1.56 & 5.26 & 34.69 & 5.29 & 13.25 & 27.85 \\
\hline & Summer & 76.5 & 8.32 & 1.53 & 1.8 & 0.09 & 1.56 & 4.19 & 30.78 & 5.16 & 10.26 & 22.58 \\
\hline & Autumn & 44.2 & 5.98 & 1.75 & 0.9 & 0.05 & 1.82 & 4.78 & 21.84 & 3.77 & 6.585 & 23.55 \\
\hline & Winter & 35.7 & 5.46 & 1.44 & 0.6 & 0.06 & 1.56 & 4.26 & 19.74 & 10.81 & 12.26 & 26.25 \\
\hline \multirow{4}{*}{ TP TW } & Spring & 134.7 & 24.96 & 4.08 & 0.3 & 0.07 & 4.16 & 3.02 & 86.16 & 0.16 & 25.25 & 46.85 \\
\hline & Summer & 73.1 & 6.24 & 2.23 & 0.6 & 0.16 & 2.08 & 2.23 & 42.16 & 0.32 & 23.54 & 33.58 \\
\hline & Autumn & 64.6 & 3.12 & 2.25 & 0.3 & 0.17 & 2.34 & 5.32 & 37.99 & 0.51 & 24.33 & 41.33 \\
\hline & Winter & 57.8 & 2.86 & 2.15 & 0.9 & 0.18 & 2.08 & 5.12 & 37.84 & 0.22 & 26.33 & 12.25 \\
\hline \multirow{4}{*}{ TP RW } & Spring & 81.6 & 7.28 & 4.51 & 0.3 & 0.17 & 4.68 & 4.98 & 80.06 & 0.78 & 19.33 & 32.53 \\
\hline & Summer & 73.1 & 8.06 & 0.25 & 0.6 & 0.21 & 0.26 & 5.96 & 40.07 & 1.09 & 15.25 & 26.54 \\
\hline & Autumn & 25.5 & 8.84 & 1.24 & 0.3 & 0.18 & 1.28 & 3.24 & 14.56 & 0.66 & 14.69 & 21.48 \\
\hline & Winter & 35.7 & 8.32 & 1.49 & 0.9 & 0.15 & 1.56 & 3.02 & 14.82 & 1.15 & 18.23 & 33.85 \\
\hline
\end{tabular}

\subsection{Statistical Analysis}

The single variance ANOVA test was used to determine the significant difference in water pollution by different ions that contribute to water salinity in Nandoni Dam at all seasons of the year. The Null hypothesis was that, there was no statistical significant difference in the concentrations of ions that affected the water salinity at different seasons of the year. That is expressed as $\mu_{1}=\mu_{2}=$ $\mu_{3}=\mu_{4}$ where $\mu_{1}, \mu_{2}, \mu_{3}$ and $\mu_{4}$ are the mean values of each parameter in spring, summer, autumn and winter respectively. F-values above 0.05 (presented in Table 6) indicated that there is a significant difference in concentrations of ions contributing to water salinity at all seasons of the year except chloride, nitrate and sodium ions.

The student $t$-test was further applied to determine if the water salinity falls within the brackish water brackets. The null hypothesis of a one-tailed test with the $\alpha=0.05$ was defined that the water in Nandoni Dam was brackish and the alternative hypothesis was that the water was fresh. The results were derived from the standard figures of fresh and brackish water presented in Tables 3 and 4 . For example, the null hypothesis was defined that the concentration of chlorides ions (that is the 
concentration in the range of 500-5000 mg/L) was in the category of brackish water. The $p$-values of the salinity and magnesium concentrations showed that the water in Nandoni Dam was brackish except the rest of the other parameters that determine if the water is brackish of not.

Table 6. The hypothetical test of the variation of the water parameters that constitutes to water salinity and the student $t$-test results.

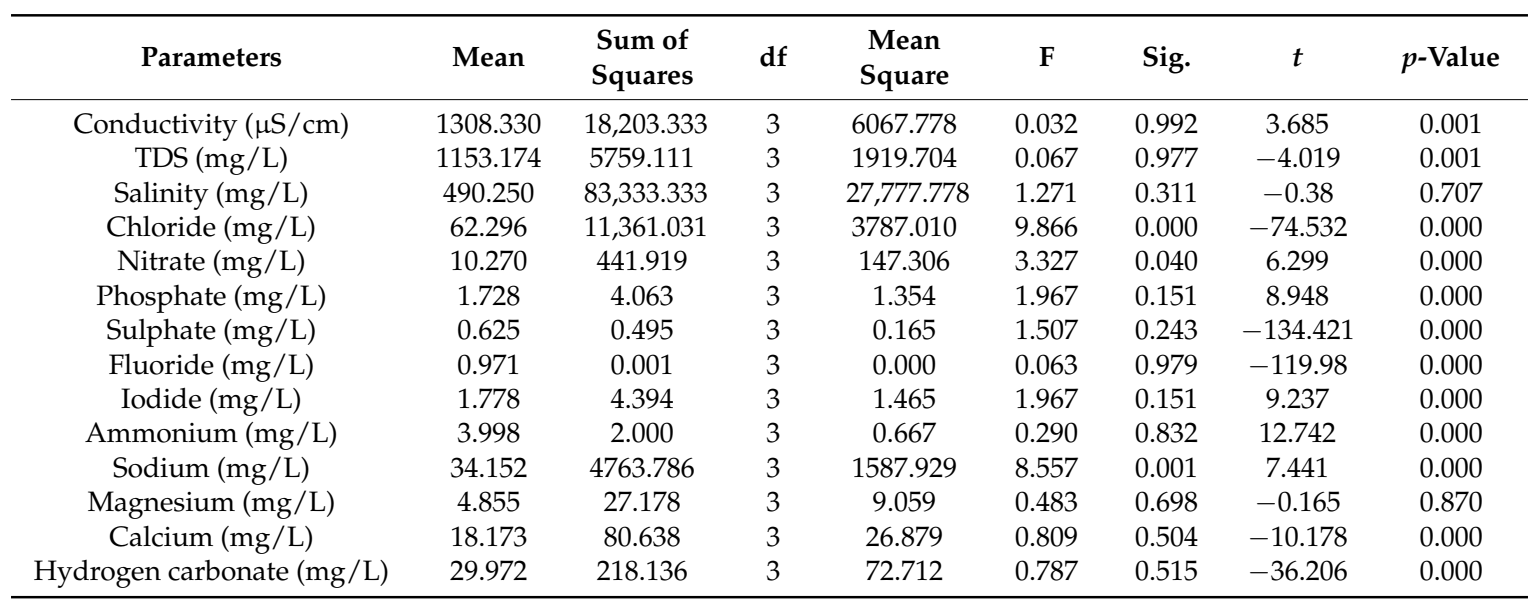

The most likely causes of salinity in the Nandoni Dam are presented in Figure 3. Such causes include the erosion of salt-bearing rocks, infiltration of the saline water from aquifers by natural and anthropogenic activities, sewage discharge and the landfill leachates that contain dissolved salts [40-43]. The contribution of the sewage discharge to the surface water salinity is less significant compared to other sources. However, it affects the quality of the water by introducing high levels of pathogens and other contaminants, thus making the water sources unfit for domestic use [44-46]. The erosion of the salt-bearing rocks are common in the Luvuvhu River and its tributaries, which are the main source of water supply for the Nandoni Dam. Source waters in the Vhembe District such as underground water and open wells are characterized by high levels of dissolved salts, which are assumed to find their way into the Nandoni Dam through small streams and tributaries that flow into the Luvuvhu River. Thus, these factors could contribute to the various levels of water salinity during different seasons of the year. The findings reported from a study conducted in Northern Cape in South Africa indicated the presence of $\mathrm{Cl}^{-1}$ and $\mathrm{Na}^{+}$ions in the river water as well as the alluvial aquifers at the concentrations of 320-14,588 mg/L and 143-4933 mg/L [47]. The main identified possible sources of the high levels of these ions were seawater intrusion, evaporitic salts dissolution, concentrations by evaporation, deep aquifer brines, dissolution of minerals from the aquifer geology as well as salts from anthropogenic activities (i.e., mining). Although this work was focused on determination of the water salinity, it was found that the quality of the water from Nandoni Dam was generally poor. The presence of ammonium in the concentration ranges of $1.32-5.96 \mathrm{mg} / \mathrm{L}$ exceeding $1.00 \mathrm{mg} / \mathrm{L}$ [48], which is the permissible WHO limits, demonstrates that the water is not only unfavourable for drinking but also toxic for both aquatic life and human use. While other anions were below the permissible limits of different organizations such as WHO, USEPA, and South African standards (SANS 241) in drinking water, the nitrates were found to be generally higher than the SANS 241 set standards of $6.00 \mathrm{mg} / \mathrm{L}$ [49]. 


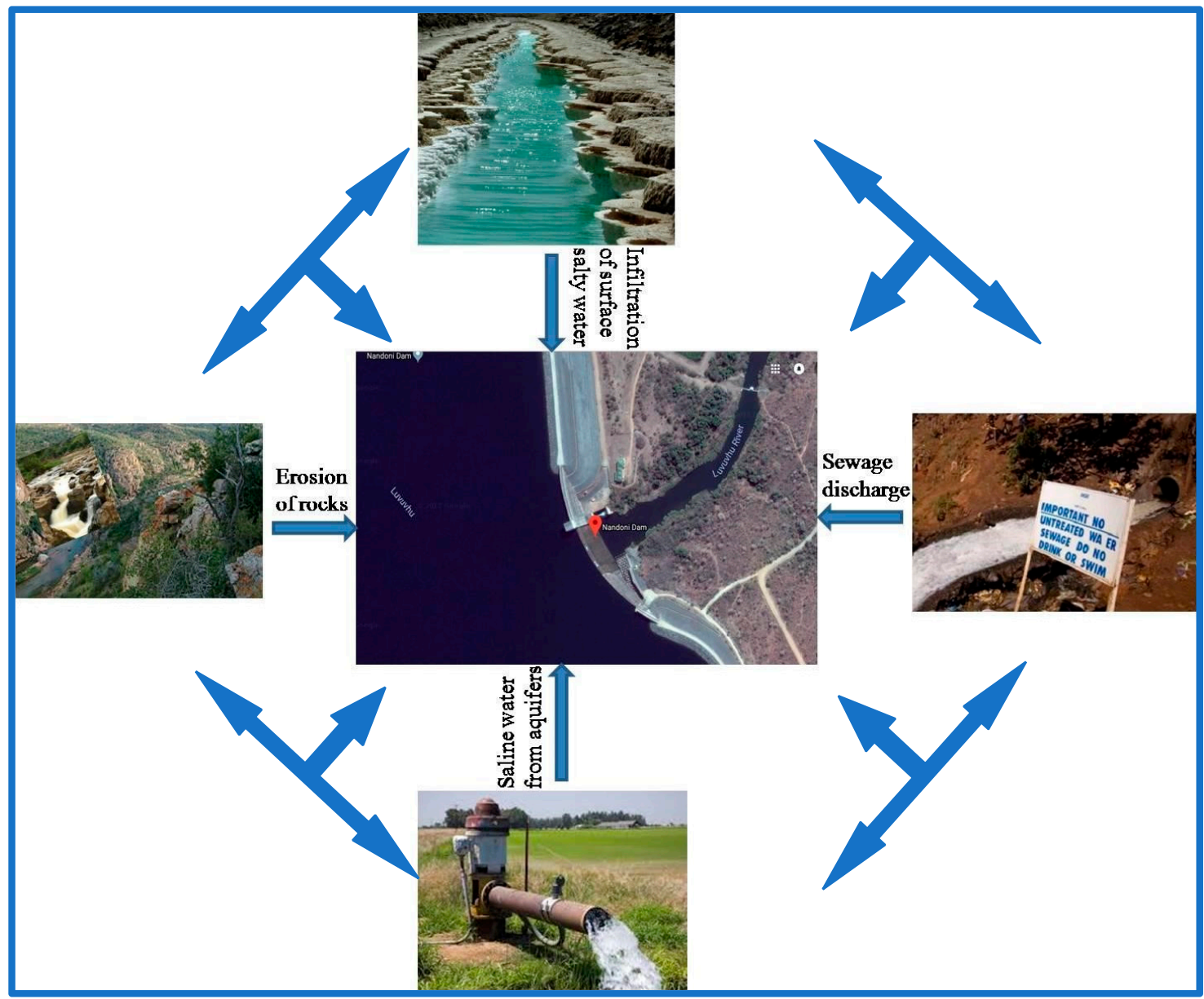

Figure 3. Possible sources of water salinity in the Nandoni Dam.

\section{Conclusions}

Salt does not only append the taste of drinking water but also provides health benefits that include healthy digestion and maintenance of the blood pressure. However, high levels of salts in a water cause an unfavourable hydrological environment that restrict its domestic purpose including drinking and use in agriculture. This study sought to classify the water salinity in the Nandoni Dam in the Vhembe District (Limpopo Province, South Africa). The concentrations of the individual ions (anions and cations) that contribute to water salinity were found to be slightly below levels found in brackish water. However, the total concentration of these dissolved ions could potentially give the water an undesirable taste that makes the water too salty for drinking purposes. Our results indicated that the water sampled across most of the Nandoni Dam was brackish during all the seasons of the year. However, some of the sites that were tested (i.e., the water at the dam outlet and the treatment plant) indicate that this water falls within the freshwater category. The concentrations of the dissolved salts in the Nandoni Dam were found to vary with seasonal changes with the highest observed in summer and autumn. Our results, therefore, indicate that the water in the Nandoni Dam is unfit for human consumption and thus needs remedial attention. This involves integrated advanced water treatment systems such as membrane water purification to minimize the impact of this water on agricultural and domestic activities which include drinking, irrigation of vegetation as well as watering of livestock. The water sourced from the Nandoni Dam is currently purified by the use of conventional treatment processes such as flocculation, coagulation, sedimentation and sand filtration. These processes are not suitable for purification of the water concentrated with dissolved salts such as sodium chloride. These ions require membrane water purification systems that produce water with high quality. 
Author Contributions: Conceptualization, S.D.M. and A.R.V.; Methodology, L.N.N.; Validation, L.N.N. and S.M.; Formal Analysis, L.N.N. and S.M.; Investigation, L.N.N. and S.M.; Resources, S.D.M., B.B.M. and A.R.V.; Writing-Original Draft Preparation, L.N.N.; Writing-Review \& Editing, L.N.N. and S.M.; Visualization, S.D.M.; Supervision, S.D.M., B.B.M., A.R.V.; Project Administration, S.D.M.; Funding Acquisition, S.D.M., B.B.M. and A.R.V.

Funding: This research was funded by the National Research Foundation (grant number: 102505), the University of South Africa and Ghent University.

Acknowledgments: The authors would like to acknowledge the National Research Foundation (South Africa), the University of South Africa and Ghent University for providing the financial support to conduct this study.

Conflicts of Interest: The authors declare no conflict of interest. The funders had no role in the design of the study; in the collection, analyses, or interpretation of data; in the writing of the manuscript, and in the decision to publish the results.

\section{References}

1. Bessong, P.O.; Nyathi, E.; Mahopo, T.C.; Netshandama, V. Development of the Dzimauli community in Vhembe District, Limpopo Province of South Africa, for the MAL-ED cohort study. Clin. Infect. Dis. 2014, 59, S317-S324. [CrossRef] [PubMed]

2. Nthunya, L.N.; Masheane, M.L.; Malinga, S.P.; Nxumalo, E.N.; Mamba, B.B.; Mhlanga, S.D. Determination of toxic metals in drinking water sources in the Chief Albert Luthuli Local Municipality in Mpumalanga, South Africa. Phys. Chem. Earth Parts A/B/C 2017, 100, 94-100. [CrossRef]

3. Frankson, L. Department Ready to Start Giyani Water Project. Available online: http:/ / www.infrastructurene. ws/2015/08/21/department-ready-to-start-giyani-water-project/ (accessed on 24 November 2017).

4. Fouche, P.S.O.; Vlok, W.; Roos, J.C.; Luus-Powell, W.; Jooste, A. Establishing the Fishery Potential of Lake Nandoni in the Luvuvhu River, Limpopo Province; WRC Report No. 1925/1/12; Water Research Commission: Gezina, South Africa, 2013. Available online: http:/ / www.wrc.org.za/KnowledgeHubDocuments / ResearchReports / 1925-1-12.pdf (accessed on 13 May 2018).

5. Polokwane Hit by Severe Water Shortage. Available online: http://www.infrastructurene.ws/2016/01/11/ polokwane-hit-by-severe-water-shortage/ (accessed on 24 July 2018).

6. National Groundwater Association (NGWA). Brackish Groundwater; NGWA: Westervill, OH, USA, 2010. Available online: http:/ / www.ngwa.org/Media-Center/briefs/Documents /Brackish_water_info_brief_ 2010.pdf (accessed on 3 January 2018).

7. World Health Organization (WHO). Manganese in Drinking Water_Background Document for Development of WHO, Guidelines for Drinking-Water Quality; WHO: Geneva, Switzerland, 2011.

8. Liu, W.C.; Liu, H.M. Assessing the impacts of sea level rise on salinity intrusion and transport time scales in a tidal estuary, Taiwan. Water 2014, 6, 324-344. [CrossRef]

9. Xing, L.; Huang, L.; Hou, X.; Yang, L.; Chi, G.; Xu, J.; Zhu, H. Groundwater hydrochemical zoning in inland plains and its genetic mechanisms. Water 2018, 10, 752. [CrossRef]

10. Zuurbier, K.G.; Stuyfzand, P.J. Consequences and mitigation of saltwater intrusion induced by short-circuiting during aquifer storage and recovery in a coastal subsurface. Hydrol. Earth Syst. Sci. 2017, 21, 1173-1188. [CrossRef]

11. Cucci, G.; Lacolla, G.; Mastro, M.A.; Caranfa, G. Leaching effect of rainfall on soil under four-year saline water irrigation. Soil Water Res. 2016, 11, 181-189. [CrossRef]

12. Joshi, D.C.; Toth, T.; Sari, D. Spatial variability of electrical conductivity of soils irrigated with brackish water in the arid region of Rajasthan, India. Ann. Arid Zone 2006, 45, 9-17.

13. Morillo, J.; Usero, J.; Rosado, D.; El Bakouri, H.; Riaza, A.; Bernaola, F.J. Comparative study of brine management technologies for desalination plants. Desalination 2014, 336, 32-49. [CrossRef]

14. Clayton, M.E.; Stillwell, A.S.; Webber, M.E. Implementation of brackish groundwater desalination using wind-generated electricity: A case study of the energy-water nexus in Texas. Sustainability 2014, 6, 758-778. [CrossRef]

15. Anyanwu, P.E.; Gabriel, U.U.; Akinrotimi, O.A.; Bekibele, D.O.; Onunkwo, D.N. Brackish water aquaculture: A veritable tool for the empowerment of Niger Delta communities. Sci. Res. Essays 2007, 2, 295-301. 
16. Cova, A.M.W.; De Freitas, F.T.O.; Viana, P.C.; Rafael, M.R.S.; Neto, A.D.D.A.; Soares, T.M. Content of inorganic solutes in lettuce grown with brackish water in different hydroponic systems. Rev. Bras. Eng. Agrícola e Ambient. 2017, 21, 150-155. [CrossRef]

17. Kim, H.; Jeong, H.; Jeon, J.; Bae, S. Effects of irrigation with saline water on crop growth and yield in greenhouse cultivation. Water 2016, 8, 127. [CrossRef]

18. Tedengren, M.; Arner, M.; Kautsky, N. Ecophysiology and stress response of marine and brackish water Gammarus species (Crustacea, Amphipoda) to changes in salinity and exposure to cadmium and diesel-oil. Mar. Ecol. Prog. Ser. 1988, 47, 107-116. [CrossRef]

19. Wu, C.S.; Kam, Y.C. Effects of salinity on the survival, growth, development, and metamorphosis of Fejervarya limnocharis tadpoles living in brackish water. Zool. Sci. 2009, 26, 476-482. [CrossRef] [PubMed]

20. He, K.; Yang, Y.; Yang, Y.; Chen, S.; Hu, Q.; Liu, X.; Gao, F. HYDRUS simulation of sustainable brackish water irrigation in a winter wheat-summer maize rotation system in the North China Plain. Water 2017, 9, 536. [CrossRef]

21. Romanoff, M.; Denison, I.A. Effect of exposure to soils on properties of asbestos-cement pipe. J. Res. Natl. Bur. Stand. 1951, 47, 367-379.

22. Abu Bakar, B.H.; Wan Ibrahim, M.H.; Megat-Johari, M.A. A review: Durability of fired clay brick masonry wall due to salt attack. Int. J. Integr. Eng. 2011, 1, 111-127.

23. Netterberg, F.; Bennet, R.A. Blistering and cracking of airport runway surfacing due to salt crystallization. In Proceedings of the 8th Conference onAsphalt Pavements for South. Africa (CAPSA'04), Sun City, South Africa, 11-16 September 2004; Document Tranformation Technologies: Centurion, South Africa, 2014; pp. 1-19.

24. Tidwell, V.C.; Moreland, B.D.; Zemlick, K.M.; Roberts, B.L.; Passell, H.D.; Jensen, D.; Forsgren, C.; Sehlke, G.; Cook, M.A.; King, C.W.; et al. Mapping water availability, projected use and cost in the western United States. Environ. Res. Lett. 2014, 9, 1-11. [CrossRef]

25. Paine, J.G. Determining salinization extent, identifying salinity sources, and estimating chloride mass using surface, borehole, and airborne electromagnetic induction methods. Water Resour. Res. 2003, 39. [CrossRef]

26. Prasad, R. Solid Waste Management and Safe Drinking Water in Context of Mizoram and other States in India; Educreation Publishing: New Delhi, India, 2011; pp. 6-11.

27. Crompton, T.R. Determination of Metals in Natural and Treated Water; Spon Press: New York, NY, USA, $2002 ;$ p. 1108.

28. Lowe, B.M.; Skylaris, C.K.; Green, N.G. Acid-base dissociation mechanisms and energetics at the silica-water interface: An activationless process. J. Colloid Interface Sci. 2015, 451, 231-244. [CrossRef] [PubMed]

29. Hassanali, A.; Prakash, M.K.; Eshet, H.; Parrinello, M. On the recombination of hydronium and hydroxide ions in water. Proc. Natl. Acad. Sci. USA 2011, 108, 20410-20415. [CrossRef] [PubMed]

30. Theeuwes, N.E.; Solcerová, A.; Steeneveld, G.J. Modeling the influence of open water surfaces on the summertime temperature and thermal comfort in the city. J. Geophys. Res. Atmos. 2013, 118, 8881-8896. [CrossRef]

31. Malmberg, C.G. Electrical conductivity of dilute solutions of 'sea water' from 5 to $120^{\circ}$ C. J. Res. Natl. Bur. Stand. A Phys. Chem. 1965, 69, 39-43. [CrossRef]

32. Rusydi, A.F. Correlation between conductivity and total dissolved solid in various type of water: A review. IOP Conf. Ser. Earth Environ. Sci. 2018, 118, 012019. [CrossRef]

33. Jonsson, J.; Smedfors, K.; Nyholm, L.; Thornell, G. Towards chip-based salinity measurements for small submersibles and biologgers. Int. J. Oceanogr. 2013, 2013, 529674. [CrossRef]

34. Sharma, A.; Kundu, S.S.; Tariq, H.; Kewalramani, N.; Yadav, R.K. Impact of total dissolved solids in drinking water on nutrient utilisation and growth performance of Murrah buffalo calves. Livest. Sci. 2017, 198, 17-23. [CrossRef]

35. Yan, N.; Marschner, P.; Cao, W.; Zuo, C.; Qin, W. Influence of salinity and water content on soil microorganisms. Int. Soil Water Conserv. Res. 2015, 3, 316-323. [CrossRef]

36. Eng, M.H.; Ita, M.K.; Urata, K.M. Quantitative analysis of chloride in brackish water: An application to the hyperchromic effect of copper (II) ion with chloride ion. Anal. Sci. 2005, 21, 95-99.

37. Alley, F.S. Ground-Water Resources for the Future, Desalination of Ground Water: Earth Science Perspectives; USGS Fact Sheet 075-03; U.S. Geological Survey: Denver, CO, USA, 2003. Available online: https:/ / pubs. usgs.gov/fs/fs075-03/ (accessed on 2 January 2018). 
38. Harris, R.R. Aspects of sodium regulation in a brackish-water and a marine species of the isopod genus Sphaeroma. Mar. Biol. 1977, 12, 18-27.

39. Srimuk, P.; Lee, J.; Fleischmann, S.; Choudhury, S.; Jäckel, N.; Zeiger, M.; Kim, C.; Aslan, M.; Presser, V. Faradaic deionization of brackish and sea water via pseudocapacitive cation and anion intercalation into few-layered molybdenum disulfide. J. Mater. Chem. A 2017, 5, 15640-15649. [CrossRef]

40. Delsman, J.R. Saline Groundwater-Surface Water Interaction in Coastal Lowlands; IOS Press: Amsterdam, The Netherlands, 2015; pp. 3-194.

41. Scarborough, R.B. Reconnaissance Geology: Salt River-From Roosevelt Dam to Granite Reef Dam, Central Arizona; 1981; Arizona Geological Survey: Tucson, AZ, USA, 2018. Available online: http:/ / repository.azgs.az.gov/ sites/default/files/dlio/files/nid1323/ofr-81-30_print_version.pdf (accessed on 9 July 2018).

42. Westbrook, S.J.; Rayner, J.L.; Davis, G.B.; Clement, T.P.; Bjerg, P.L.; Fisher, S.J. Interaction between shallow groundwater, saline surface water and contaminant discharge at a seasonally and tidally forced estuarine boundary. J. Hydrol. 2005, 302, 255-269. [CrossRef]

43. Nergis, Y.; Sharif, M.; Choudhry, A.F.; Hussain, A.; Butt, J.A. Impact of industrial and sewage effluents on Karachi coastal water and sediment quality. Middle-East J. Sci. Res. 2012, 11, 1443-1454.

44. Nthunya, L.N.; Masheane, M.L.; Malinga, S.P.; Edward, N.; Barnard, T.G.; Kao, M.; Tetana, Z.N.; Mhlanga, S.D. A greener approach to prepare electrospun antibacterial cyclodextrin/cellulose acetate nanofibres for removal of bacteria from water. ACS Sustain. Chem. Eng. 2016, 5, 153-160. [CrossRef]

45. Owili, M.A. Assessment of Impact of Sewage Effluents on Coastal Water Quality in Hafnarfjordur, Iceland; Icelandic Fisheries Laboratories: Reykjavik, Iceland, 2003.

46. Nthunya, L.N.; Masheane, M.L.; Malinga, S.P.; Barnard, T.G.; Nxumalo, E.N.; Mamba, B.B.; Mhlanga, S.D. UV-assisted reduction of in situ electrospun antibacterial chitosan-based nanofibres for removal of bacteria from water. RSC Adv. 2016, 6, 95936-95943. [CrossRef]

47. Nakwafile, A.N. Salinisation Source(s) and Mechanism(s) in Shallow Alluvial Aquifers along the Buffels River, Northern Cape Province, South Africa. Master's Thesis, Stellenbosch University, Western Cape Province, South Africa, 2015.

48. WHO. Ammonia in Drinking-Water: Background Document for Development of WHO Guidelines for Drinking-Water Quality; WHO: Geneva, Switzerland, 2003. Available online: http://www.who.int/water_sanitation_health/ dwq/ammonia.pdf (accessed on 9 July 2018).

49. Department of Water Affairs and Forestry (DWAF). South African Water Quality Guidelines: Volume 1 Domestic Use; DWAF: Pretoria, South Africa, 1996. Available online: http://www.dwa.gov.za/iwqs/wq_guide/Pol_ saWQguideFRESH_vol1_Domesticuse.PDF (accessed on 9 July 2018). 